ISSN: 2224-0616

Int. J . Agril. Res. Innov. \& Tech. 3 (1): 73-77, June, 2013 Available online at http:// www.ijarit.webs.com

\title{
COMPARATIVE PROFITABILITY OF ONIONS HARVESTED AS GREEN AND DRY (MATURE) IN BOTSWANA
}

\author{
S.P. Baliyan ${ }^{1}$ and P.S. Baliyan ${ }^{2}$ \\ Received 30 April 2013, Revised 29 May 2013, Accepted 20 June 2013, Published online 30 June 2013
}

\begin{abstract}
This study was an attempt to calculate and compare the profitability of onions harvested as green and dry (mature) in Botswana. Half of the planted onions were harvested and sold as green and half were harvested and sold as dry onions. The cost of production of green onions was $32.78 \%$ higher than the cost of production of dry onions. The irrigation and marketing expenses contributed the highest difference in the cost of production of green and dry onions. The major cost item contributing to the cost of green onions production was marketing cost (32.86\%) followed by irrigation cost (23.77\%) and harvesting cost (18.53\%) whereas the highest cost of production for dry onions was contributed by irrigation (38.58\%) followed by marketing (19.45\%) and planting (11.96\%). The marketing cost for green onions was almost double (35.6\%) as compare to the dry onions (18.2\%). The total return from green onions was $50.90 \%$ higher than the returns from dry onions. Gross margin of onions harvested as green was $63 \%$ higher than the gross margin from dry onions, which indicated that the production of green onions is more profitable as compare to production of dry onions. The farmers preferred onion harvested as green because it generates regular and higher returns than onions harvested as mature. Government should support farmers through some policies such as Minimum Support Price (MSP) for dry onions, distribution of Mini Ferti-Seed Kit (Seeds of improved varieties and fertilizer package), construction of storages and formation of cooperatives.
\end{abstract}

Keywords: Variable Cost, Returns, Gross Margin, Profitability, Green and Mature Onions

${ }^{1}$ Department of Agriculture, Livingstone Kolobeng College, Gaborone, Botswana

${ }^{2}$ Department of Accounting and Finance, Faculty of Business, University of Botswana, Gaborone, Botswana

*Corresponding author's email: spbaliyan@yahoo.com (S.P. Baliyan)

\section{Introduction}

Onions (Allium cepa L.) originated in mid-Asia what are now Northwestern India, Afghanistan, Tajik, and Uzbek. Onion relatives include shallots, scallions (bulb onions), rakkyo, spring onions and chives (Hamasaki et al., 1999). Onions are important vegetable crops in most parts of the world, particularly the varieties that are grown for bulbs. In terms of global weight of vegetables produced, at nearly 28 million tons per annum, only tomatoes and cabbages exceed bulb onions. Onion is one of the oldest bulb vegetables in continuous cultivation dating back to at least 4000 BC (Ahmad et al., 2008; Hayslip et al., 1987). Onions have been used as a condiment in the cuisines of ancient China, India, and Egypt for well over 4000 years. Onions are grown mainly as food materials however, it has its medicinal value. Although its main role in cooking is to provide flavor, onion is a significant source of vitamin C

Table 1. Area and production of onions in Botswana

\begin{tabular}{lcccccc}
\hline Year & 2006 & 2007 & 2008 & 2009 & 2010 & 2011 \\
\hline Area (ha) & 28 & 30 & 26 & 25 & 27 & 31 \\
Production (Tons) & 448 & 481 & 554 & 521 & 585 & 664 \\
\hline
\end{tabular}

Source: FAO (2012) and potassium, contains about 60 calories in a medium-sized bulb, and has very low sodium content. The bulbs are boiled and used in soups and stews, fried or eaten raw. They are also preserved in the form of pickles. Onion leaves, especially the spring onion, are also used in salads and soup. Onion have long been used by many cultures for the treatment of various ailments such as skin diseases, ear pain, heart attack and strokes, and modern science is beginning to reveal more potential health and medicinal benefits of onions.

Onion is a cash crop and grown well in winter season throughout Botswana. The production of onions in Botswana is very low which can only meet $18 \%$ of the local demand and therefore, the country depends on import of dry (mature) onions from neighboring countries, especially South Africa (Table 1). 
It is evidenced that the growth in area and production of onions in year 2011 (base 2006) has been $10.71 \%$ and $48.21 \%$, respectively. Onions can be harvested and consumed as green and mature (dry). The term dry onion is used to distinguish them from green onions, which are pulled while the tops are still green and usually before a large bulb has formed (Torrance, 1998; Hochmuth et al 1985). Most of the onions harvested in the Botswana are sold as green because farmers perceive and consider that the green harvested onions provide higher returns as compare to the dry harvested onions. Harvesting of onions as green has been a main reason for low production of dry onions in the country, which leads to dependency on imported onions. Farmers are of view that harvesting onions as green not only more profitable than harvesting mature onions but also provide enough time to prepare their fields for planting next crop and therefore, they prefer harvesting onions as green. However, farmers do not keep proper records to support and justify their perception that the harvesting of green onions is more profitable than the dry onions. Moreover, there is no research work available on the cost of production of onions and comparing the profitability of production of green and mature onions in Botswana. Therefore, this study was conducted on the farmer's field to compare the profitability of green and dry harvested onions. The specific objectives of this study was to calculate and compare the costs, returns and gross margin of green and mature (dry) harvested onions.

\section{Material and Methods}

The study was a Researcher Managed and Farmer Implemented (RMFI) experimental study. The experiment was conducted in the Ngamiland Region of Botswana. A purposive selection method was adopted whereby one farmer's field was purposively selected. The limited availability of resources with the researcher and, the availability of the committed and educated farmers were the two major reasons for selection of the only one farmer through purposive selection method. The seedlings of a common and recommended onion variety for Botswana (Texas Grano 502 PRR) were raised in seedbed and 6-8 weeks old seedlings were then transplanted in a prepared field. The size of plot was $100 \mathrm{~m} \times 100$ $\mathrm{m}$ (1 ha) for green onion as well as for dry (matured) onions. The spacing of planting onions was $30 \mathrm{~cm} \times 7.5 \mathrm{~cm}$. All the recommended practices in onion cultivation were followed (Nakagawa, 1957). Half of the area was considered as green onions and half was left for onions to dry. The green onions were harvested twice a week and were sold in one $\mathrm{kg}$ pack containing 4-6 plants with bulb onions. The dry onions were harvested once at maturity stage (80\% tops down). The harvested onions were left to dry for a week before dry leaves were removed. The dried onions were sold in packs of either one $\mathrm{kg}$ or two kg packs depending on the consumer's preference in the local market at retail price.

The data on inputs and outputs were recorded by the farmer in the record sheets prepared and provided by the researcher. The data collection records were checked and monitored closely by the researcher. The inputs data were recorded activity wise e.g. land preparation, planting, fertilization, irrigation, harvesting, marketing etc. The output data included the yield, price and returns of onions. The cost of production, gross returns and gross margin were calculated (Boehlje and Vernon, 1984) separately for green harvested onions and dry harvested onions. The cost, returns and gross margin were calculated and compared for green and dry onions. The actual market retail price was considered in calculating the costs and returns from green and dry onions. The data were analyzed using simple mathematical tools such as addition, multiplication, subtraction and percentage. Farmer's views on cultivation of onions as green and mature were also collected through direct interview with the farmers. In order to obtain farmers perceptions, focus group interviews were held with groups of horticultural farmers to enable a process of dialogic discussion and interaction between respondents and the researcher. The focus group is an established method of social inquiry (Krueger, 1998) and a reliable and cost effective method to obtain the perception on any aspect. A group of 30 farmers was invited to visit twice the experiment site and was asked for their perceptions on the preference of harvesting of onions as green and mature.

\section{Results and Discussion}

The item wise cost of production of green and mature (dry) is presented in Table 2 . The cost of green onions production was $32.78 \%$ higher than the cost of dry onions production. It was found that $75 \%$ of the cost for both types of onions was contributed by cost of irrigation, harvesting and marketing. The major cost item of green onions production was marketing cost (32.86\%) followed by irrigation (23.77\%) and harvesting (18.53\%) whereas the highest cost of production for dry onions was contributed by irrigation (38.58\%) followed by marketing (19.45\%) and planting (11.96\%).The lowest cost of production was contributed by fertilization (topdressing) which was $0.82 \%$ and $1.09 \%$ for green and mature onions, respectively. The plant protection costs for dry onions were almost double (3.20\%) than the plant protection costs for green onions (1.73\%). The difference in plant protection cost 
was due to the use of pesticide and fungicides in dry onions while no pesticides and fungicides were used in production of green onions.

The marketing cost for green onions was almost double $(32.86 \%)$ as compare to the dry onions (19.2\%) reason being the time consumed in frequent selling of green onions in the local retail market. The marketing cost of green onions could be significantly reduced by bulk harvesting and selling to the wholesalers, as it will reduce the frequent visit to market for selling green onions. The cost items for land preparation, planting, fertilization, plant protection and irrigation for green onions were lower by $1.85 \%, 2.95 \%, 0.27 \%$, $1.47 \%$ and $14.81 \%$ as compare to the respective cost items for dry onions.

Table 2. Cost of production of onions harvested as green and mature (dry) ( $\left(\mathrm{P} \mathrm{ha}^{-1}\right)$

\begin{tabular}{lcc}
\hline \multirow{2}{*}{ Cost Items } & \multicolumn{2}{c}{ Cost $(\mathrm{P} \mathrm{ha} 1)$} \\
\cline { 2 - 3 } & Green onions & Mature onions \\
\hline 1. Land preparation & $7320.00(5.64)$ & $7320.00(7.49)$ \\
2. Planting & $11686.00(9.01)$ & $11686.00(11.96)$ \\
3. Fertilization & $1064.00(0.82)$ & $1064.00(1.09)$ \\
4. Plant protection & $2250.00(1.73)$ & $3130.00(3.20)$ \\
5. Irrigation & $30834.00(23.77)$ & $37686.00(38.58)$ \\
6. Harvesting & $24034.00(18.53)$ & $10995.00(11.26)$ \\
7. Marketing & $42615.00(32.86)$ & $19007.00(19.45)$ \\
8. Operating overhead & $9902.00(7.63)$ & $6797.00(6.96)$ \\
Total Variable Cost (1-8) & $129706.00(100.00)$ & $97685.00(100.00)$ \\
\hline
\end{tabular}

Figures in parenthesis are the percentages to total variable cost

$P$ refers to Pula, the Botswana currency

The highest difference in the cost of production of green and dry onions is contributed by the irrigation and marketing. The cost of irrigation for green onions (P30834) was lower by $14.81 \%$ as compare to the irrigation cost of dry onions (P37686). Higher number of irrigation contributed to the high irrigation cost for dry onions. The growing period for dry onions was higher by 6-8 weeks as compare to the period for green onions (Ali et al., 2005). However, marketing cost for green onions was higher by $13.41 \%$ than the marketing cost for dry onions. Higher number of harvesting and frequent visit to market for their sell contributed to the high marketing cost for green onions. The Marketing costs included transportation cost, packing and loading and unloading charges. The marketing costs are crucial as they contribute significantly to the total cost of onion production, which makes difference in profit margin (Ahmad et al., 2008; Kline, 1997).

The yield, returns and gross margin of onions harvested as green and mature (dry) are presented in Table 3. The numbers of green onions harvested were 368200 whereas the weight of onion bulbs harvested dry was 61000 $\mathrm{kg}$. Total return from green onions calculated P368200, which is $50.90 \%$ higher than the gross returns obtained from dry onions (P244000). Gross margin of onions harvested as green was calculated at P238494 which is higher by $63 \%$ as compare to the gross margin obtained from dry onions (P146315) which indicates that the production of green onions is more profitable as compare to production of dry onions. These results confirm the view of the onion growers that the onions harvested as green are more profitable than dry onions.

Table 3. Yield, Returns and Gross Margin of onions harvested as green and mature (dry)

\begin{tabular}{lcc}
\hline Particulars & Green onions & Mature onions \\
\hline Yield* & 368200 & 61000 \\
Returns (P/ha) & 368200 & 244000 \\
Total Variable Costs (P/ha) & 129706 & 97685 \\
Gross Margin (P/ha) & 238494 & 146315 \\
\hline
\end{tabular}

* Yield for green onions is the number of green plants/ bulbs and, for mature onion is the weight of dry onion bulbs in $\mathrm{Kg}$

In order to know the views of onions growers, farm visits were conducted twice during the period of experiment where 30 farmers participated and expressed their views. The farmer's views on production of onions as green and mature (dry) indicated that onion harvested as green was preferred by $93 \%$ farmers (28 out of 30 farmers interviewed) because it generates regular and higher returns than onions harvested as mature. This view is justified by the results of the study indicate that the green onions generate $50.9 \%$ higher returns as compare to dry onions. 
The land can also be cleared some weeks (about 6-8 weeks) before dry onions and hence can be used for next crop. Onions harvested as green are perishable and have to be sold quickly after harvesting which increases in the cost of harvesting and marketing of green onions. However, the income from green onions can not sustain for long period of time whereas dry onions can provide a regular source of income. Storage of dry onions is a challenging constraint for farmers as they do not have proper storage facility and skills and which forces farmers to harvest onions as green rather than dry (mature).

\section{Conclusion and Recommendations}

Despite of the fact that cost of production of green onions was higher by $32.78 \%$ than the cost of production of dry onions, the gross margin for green onions was found higher by $63 \%$. Therefore, it can be concluded that harvesting of onions as green is more profitable as compare to dry onions.

This study has its implications on the onions growers as well on the policy makers. The results support the perception among the onion growers that harvesting green onions is more profitable than harvesting mature onions. The results may have impact on the high acreage of onions but might be harvested as green rather than dry onions. However, the onion growers should also be careful of decline in price and therefore returns, if all the farmers are harvesting their onions as green and at the same time because of excess supply in the market. In order to avoid the high supply of green onions in the local market, the growers are suggested to plant onions after a significant interval to ensure adequate and sustainable supply in the market. Reduction in frequent visit to market for selling onions, especially green onions can reduce the cost of production leading to increase in the profit.

The agricultural policy makers should have effective policies so as to attract farmers to grow onions and then ensure harvesting as mature onions. Government may introduce policies to attract, promote and protect farmers for planting onions and harvest them dry. It is suggested that government should have a policy on the Minimum Support Price (MSP) for dry onions so as the farmers can feel secured in planting, selling and getting a reasonable profit from harvesting their onions as dry. The government can provide the potential farmers with economy Mini Ferti - Seed Kit (Seeds of improved onion varieties and fertilizer package), especially for high yielding onion varieties. Government should encourage and support farmers to form cooperatives enabling them to build the onion storage facilities, which will enhance harvesting and selling dry onions.

\section{Acknowledgement}

The corresponding author would like to acknowledge the Department of Agricultural Research, Ministry of Agriculture, Republic of Botswana for providing the opportunity to conduct this study during his tenure as an Agricultural Research Officer. $\mathrm{He}$ is very thankful to Mr. Ramakgalo for offering his farm and facilities and, also for maintaining all the necessary records.

\section{References}

Ahmad, S., Chohan, T.Z. and Saddozai, K.N.. 2008. An investigation into cost and revenue of onion production in Azad Jammu Kashmir. Sarhad J. Agric. 24 (4): 737-743.

Ali, A., Niazi, M.A. and Akmal, N. 2005. Comparative analysis of cost and return of potato, onion and tomato in Balouchistan. Sarhad J. Agric. 21 (4): 785791.

Boehlje Michael, D. and Vernon R. Eidman. 1984. Farm Management. John Wiley and Sons. New York, NY. pp. 806.

FAO. 2012. Production Year Book: Food and Agriculture Organisation, Rome, Italy.

Hamasaki, R., Valenzuela, H. and Shimabuku, R. 1999. Bulb onion growing in Hawaii. College of Tropical Agriculture and Human Resources, University of Hawaii, Manoa, Hawaii. $52 \mathrm{p}$.

Hayslip, N.C., Gull, D.D., Guzman, V.L., Shumaker, J.R. and Sonoda, R.M. 1987. Bulb onion production in Florida. FL Coop. Ext. Svc. Bull. 238 p.

Hochmuth, G.J., Hewitt, T.D. and Ruppert, K.C. 1985. Bulb onion production review. FL Coop. Ext. Svc. Memo. 23 p.

Kline, W.L. 1997. Production, marketing and postharvest handling of onions in Central America. NY State Veg. Conf. Proc., Feb. 1113, 1997. pp. 185- 188.

Krueger, R.A. 1988. Focus Groups: A Practical Guide for Applied Research. Newbury Park, CA: Sage. 179p.

Nakagawa, Y. 1957. Bulb onion growing in Hawaii. HI Coop. Ext. Svc. Ext. Circ. 385 p.

Torrance, R. 1998. Onion production in Georgia. NY State Veg. Conf. Proc., Feb. 10- 12, 1998. pp. 189- 191. 
Appendix 1. Pictures of onions harvested as green and dry

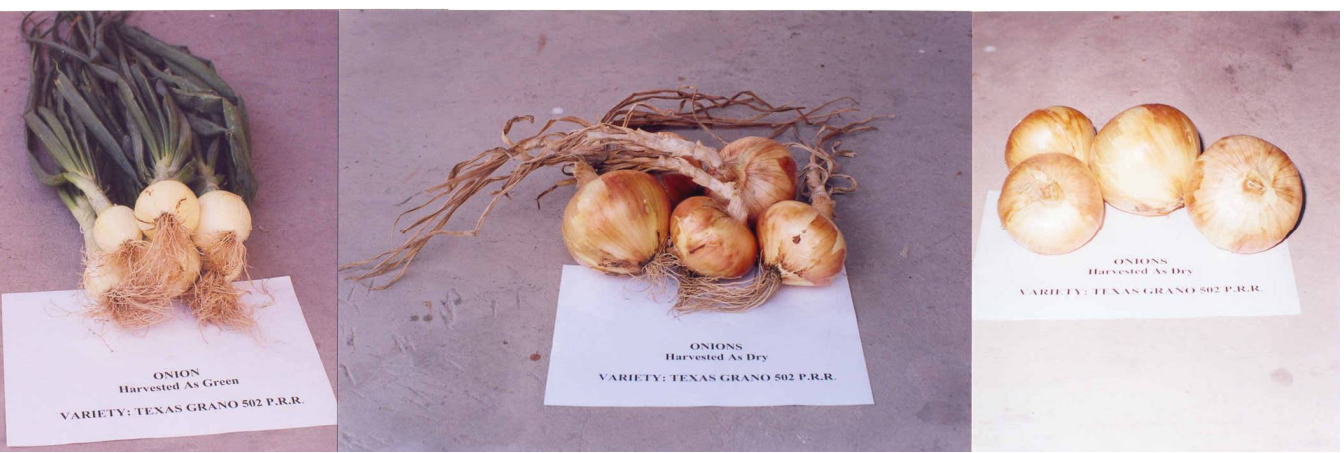

Appendix 2. Item wise cost of production of onions harvested as green and mature (dry) ( $\left(\mathrm{Ph}^{-1}\right)$

\begin{tabular}{|c|c|c|}
\hline Cost Items & Green Onions & Mature Onions \\
\hline \multicolumn{3}{|l|}{ 1. Land Preparation } \\
\hline Fertilizer 2:3:2 & 2745.00 & 2745.00 \\
\hline Labour to prepare land & 3375.00 & 3375.00 \\
\hline Ploughing \& discing & 1200.00 & 1200.00 \\
\hline Total Land Preparation cost & 7320.00 & 7320.00 \\
\hline \multicolumn{3}{|l|}{ 2. Planting } \\
\hline Seeds & 1080.00 & 1080.00 \\
\hline Fertilizer 2:3:2 & 275.00 & 275.00 \\
\hline Urea & 207.00 & 207.00 \\
\hline Labour to raise \& transplanting seedlings & 10124.00 & 10124.00 \\
\hline Total Planting Cost & 11686.00 & 11686.00 \\
\hline \multicolumn{3}{|l|}{ 3. Fertilization } \\
\hline Fertilizer Urea & 689.00 & 689.00 \\
\hline Labour to apply fertilizer & 375.00 & 375.00 \\
\hline Total Fertlization Costs & 1064.00 & 1064.00 \\
\hline \multicolumn{3}{|l|}{ 4. Plant Protection } \\
\hline Labour to weed \& till & 2250.00 & 2250.00 \\
\hline Chemicals & 00.00 & 880.00 \\
\hline Total Plant Protection Cost & 2250.00 & 3130.00 \\
\hline \multicolumn{3}{|l|}{ 5. Irrigation } \\
\hline Cost of Water & 20709.00 & 25311.00 \\
\hline Labour to apply water & 10125.00 & 12375.00 \\
\hline Total Irrigation Cost & 30834.00 & 37686.00 \\
\hline \multicolumn{3}{|l|}{ 6. Harvesting } \\
\hline Labour to harvest \& pack & 16875.00 & 9000.00 \\
\hline Packaging material & 7160.00 & 1995.00 \\
\hline Total Harvesting cost & 24035.00 & 10995.00 \\
\hline \multicolumn{3}{|l|}{ 7. Marketing } \\
\hline labour to transport to market \& sale & 16875.00 & 7875.00 \\
\hline Fuel to transport to market & 25740.00 & 12012.00 \\
\hline Total Marketing cost & 42615.00 & 19887.00 \\
\hline \multicolumn{3}{|l|}{ 8. Operating Overhead } \\
\hline Operating interest & 697.00 & 697.00 \\
\hline Management & 9205.00 & 6100.00 \\
\hline Total Operating Overhead & 9902.00 & 6797.00 \\
\hline TOTAL VARIABLE COST: (1- 8) & 129706.00 & 97685.00 \\
\hline
\end{tabular}

